\title{
Milk protein polymorphism in Swiss dairy cattle
}

\author{
FAWZY TAHA and ZDENKO PUHAN
}

TAHA, F. \& PuHAn, Z. 1993. Milk protein polymorphism in Swiss dairy cattle. Agric. Sci. Finl. 2: 423-429. (Lab. Dairy Sci., Swiss Federal Inst. Techn., CH-8092 Zürich, Switzerland.)

Individual cow milk samples from (a) 208 original Swiss Simmental (OSS), (b) 220 of their crosses $($ Simmental cattle $=$ FV) with American Red Holstein $($ RH), (c) 215 original Swiss Brown (OSB) and (d) 390 of their crosses (Brown cattle = BV) with American Brown Swiss (BS) were genotyped for the variants of milk caseins (Cn) and $\beta$-Lactoglobulin $(\beta-\mathrm{Lg})$. In addition, the association between $\kappa$ - $\mathrm{Cn}$ genotypes and milk yield was studied.

Reasonable differences in the allele frequencies were found between the breeds. Compared to pure-bred OSS, crossing with $\mathrm{RH}$ resulted in a decrease in the frequencies of $\alpha_{\mathrm{si}}-\mathrm{Cn} \mathrm{C}, \beta-\mathrm{Cn} \mathrm{B}$ and $\kappa-\mathrm{Cn} \mathrm{B}$ and in an increased frequency of $\beta-\mathrm{Lg} \mathrm{B}$. Within OSB, increased crossing with BS resulted in a decrease in the frequencies of $\alpha_{\mathrm{s}}-\mathrm{Cn} \mathrm{C}$ and $\beta-\mathrm{Cn} \mathrm{B}$ and in increased frequencies of $\kappa-\mathrm{Cn} \mathrm{B}$ and $\beta-\mathrm{Lg} \mathrm{B}$.

A significant association between the $\kappa-\mathrm{Cn}$ locus and milk yield could only be shown for the OSS breed.

Key words: Swiss dairy cattle, milk protein polymorphism, kappa-casein and milk yield

\section{Introduction}

In the past, dairy cattle breeders paid more attention to quantitative criteria (yield and fat content of milk) than to other criteria. Lately, however, milk protein polymorphism (qualitative criteria) has received considerable attention from the dairy industry because of its effect on the manufacturing properties of milk and the yield and quality of the products. Consequently, in the last 30 years the distribution of the genetic variants of milk proteins caseins $(\mathrm{Cn})$ and $\beta$-lactoglobulin $(\beta-\mathrm{Lg})$ - in different breeds has been studied and the possible benefits of considering protein genotypes in selection programmes have been discussed. The vast number of studies on the association between protein polymorphism and the physiochemical properties of milk in different breeds has recently been reviewed by JАKOB and PUHAN (1992). The main results were that there are favourable milk protein variants which are associated with the technological properties of milk: $\alpha_{\mathrm{s} 1}-\mathrm{Cn} \mathrm{C}$ is associated with firmer curd, $\beta$-Cn B with shorter coagulation times, $\beta$ - $\mathrm{Lg}$ $B$ with high casein number and $\kappa-\mathrm{Cn} B$ with shorter renneting time (DAVIES and LAW 1977, KROEKER et al. 1985, SCHAAR 1984, JAKOB and PUHAN 1986, MARIANI et al. 1976, TERVALA et al. 1985, MARZIALI and NG-KWAI-HANG 1986, MCLEAN 1986, AALTONEN and ANTILA 1987).

Reports on the association between $\kappa$ - $\mathrm{Cn}$ genetic variants and milk yield are somewhat conflicting. Whereas ALEANDRI et al. (1990) and NG-KWAIHANG et al. (1990) found no significant associations, results from other groups (LIN et al. 1989) indicate that there is indeed a relationship. However, because of economic interests, it has been 
suggested that favourable milk protein genotypes, $\alpha_{\mathrm{sl}}-\mathrm{Cn} \mathrm{CC}, \beta-\mathrm{Cn} \mathrm{BB}, \kappa-\mathrm{Cn} \mathrm{BB}$ and $\beta$-lactoglobulin $\mathrm{BB}$, should be included into the criteria for selecting dairy cattle.

The objectives of this investigation were to study the frequencies of the genetic variants of $\alpha-, \beta$-, $\kappa-\mathrm{Cn}$ and $\beta$ - $\mathrm{Lg}$ in two original Swiss breeds and in their crosses with two related American breeds and to analyze the association between $\kappa$ - $\mathrm{Cn}$ genetic variants and milk yield. The reason for including only $\kappa$-Cn variants in the statistical analysis was that the Braunvieh Cattle Breeders Federation in Switzerland has decided to consider these variants in breeding programmes; animals with $\kappa-\mathrm{Cn} \mathrm{BB}-$ and/or AB type are recommended for planned matings (ZOGG 1990).

\section{Material and methods}

\section{Animal material}

The two main dairy breeds in Switzerland are Simmental cattle, known in Switzerland as "Simmentaler Fleckvieh" (FV), and Brown cattle, known in Switzerland as "Braunvieh" (BV). FV are crosses between original Swiss Simmental (OSS) and American Red Holstein (RH), and BV are crosses between original Swiss Brown (OSB) and American Brown Swiss (BS). Together they represent $87.90 \%$ (Simmental cattle $=45.51 \%$ and Brown cattle $=42.39 \%$ ) of the total recorded cows $(593,361)$. Only a few farmers still breed OSS and OSB.

Within one week a total of 1,033 individual milk samples from 68 farms were analyzed, representing the following dairy breeds in Switzerland:

- Original Swiss Simmental = OSS

- Simmental cattle (crosses OSS $x$ RH) $=F V$

- Original Swiss Brown = OSB

- Brown cattle $($ crosses OSB x BS) = BV

The milk was genotyped for variants of $\alpha_{\mathrm{s} 1-} \mathrm{Cn}$, $\beta-\mathrm{Cn}, \kappa-\mathrm{Cn}$ and $\beta-\mathrm{Lg}$ using isoelectric focusing (SEIBERT et al. 1985).

\section{Statistical analysis}

To study the association between $\kappa$ - $\mathrm{Cn}$ variants and milk yield (305-day lactation yield), an analysis of variance was carried out using the General Linear Model (GLM) Procedure Type SSIII (SAS 1988). The model included the fixed effects of $\kappa$-Cn locus and lactation number as classification variables. Only the phenotypes $\kappa-\mathrm{Cn} \mathrm{AA}, \mathrm{AB}$ and $\mathrm{BB}$ were included, but not phenotypes including $\kappa-\mathrm{Cn} \mathrm{C}$ and $\mathrm{E}$ alleles because of their low frequencies in this material (Table 2). The herd effect was ignored because from some farms less than 5 , from others more than 30 records were available. Sires were not included in the model because of lack of data for sires used in the studied original Swiss breed herds (OSS and OSB).

The officially recorded milk yield, i.e., a 305-day lactation yield, was used in the statistical analysis. First-lactation records as well as records of cows with a lactation number higher than 10 were excluded because they were not available for all breeds. Moreover, 67 samples were excluded because of identification difficulties of their casein variants, leaving 954 samples for statistical analysis.

The model used to analyze the data was

$\mathrm{Y}_{\mathrm{ijk}}=\mu+\mathrm{V}_{\mathrm{i}}+\mathrm{L}_{\mathrm{j}}+\mathrm{e}_{\mathrm{ijk}}$

where:

$\mathrm{Y}_{\mathrm{ijk}}=$ milk yield of the $i j \mathrm{k}^{\text {th }}$ individual

$\mu=$ overall mean

$\mathrm{V}_{\mathrm{i}}=$ fixed effect of the $\mathrm{i}^{\text {th }} \kappa$-Cn allele $(\mathrm{i}=\mathrm{AA}, \mathrm{AB}$ and $\mathrm{BB}$ )

$L_{j}=$ fixed effect of the $j^{\text {th }}$ lactation number $(j=2$, $3, \ldots, 10)$

$\mathrm{e}_{\mathrm{ijk}}=$ residual random term

\section{Results and discussion}

\section{Allele frequencies of $\alpha_{\mathrm{s} 1^{-}}, \beta-\mathrm{Cn}$ and $\beta-\mathrm{Lg}$}

The allele frequencies are shown in Table 1. Regarding homozygote genotypes of the favourable genetic variants, $\alpha_{\mathrm{sl}}-\mathrm{Cn} \mathrm{CC}, \beta-\mathrm{Cn} \mathrm{BB}$ and $\beta-\mathrm{Lg}$ 
Table 1. Allele frequencies of $\alpha_{51}, \beta$ - and $\kappa$-casein and $\beta$-lactoglobulin for original Swiss Brown and Simmental cattle and their crosses with American Brown Swiss and Red Holstein.

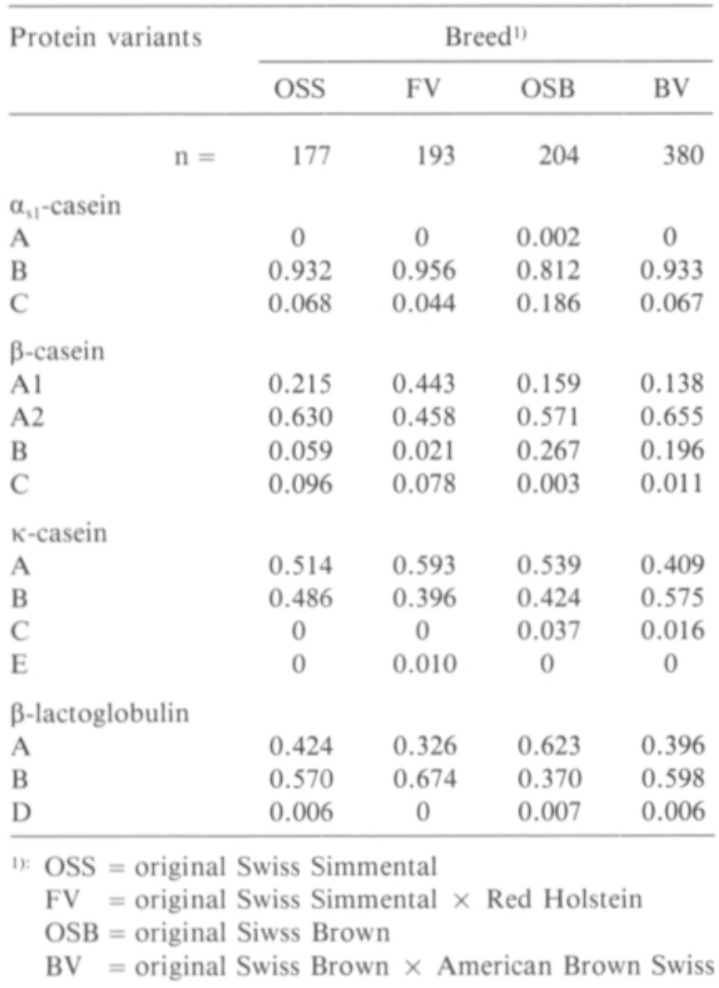

$\mathrm{BB}$, differences were found between the breeds (Table 2). Contrary to the OSB and BV population, the rare $\mathrm{C}$ allele of $\alpha_{\mathrm{s} 1}-\mathrm{Cn}$ appeared only in heterozygous $(\mathrm{BC})$ of the OSS and FV population. The rare $A$ allele of $\alpha_{s 1}-C n$ was found in the OSB population and appeared only in a heterozygous form (AB).

In OSS, the frequencies of $\alpha_{\mathrm{s}}-\mathrm{Cn} \mathrm{C}$ and $\beta-\mathrm{Cn} \mathrm{B}$ $(0.068$ and 0.059$)$ were higher than in FV $(0.044$ and 0.021$)$, whereas the opposite was true for $\beta-\mathrm{Lg}$ $\mathrm{B}$ (0.570 compared to 0.674$)$. In comparison, the average frequencies for $\alpha_{\mathrm{s} 1-} \mathrm{Cn} \mathrm{C}, \beta-\mathrm{Cn} \mathrm{B}$ and $\beta$ - $\mathrm{Lg} \mathrm{B}$ for the Holstein breed are 0.03, 0.02 and 0.61 , respectively (NG-KWAI-HANG et al. 1984, MCLEAN et al. 1984, ALEANDRI et al. 1990). A comparison of the allele frequencies of the Holstein breed and OSS showed that the allele frequencies of FV are between these breeds. For the German Simmental cattle population, the allele frequencies were 0.09 for $\alpha_{\mathrm{s1}}-\mathrm{Cn} \mathrm{C}, 0.07$ for $\beta$-Cn B and 0.53 for $\beta$ - Lg B (SEIBERT et al. 1987), which are close to those shown for OSS. This indicates that German Simmental cattle is crossbred with $\mathrm{RH}$ to a lesser degree than FV in Switzerland.

Differences were also found between OSB and BV. In OSB, the frequencies of $\alpha_{\mathrm{s} 1-} \mathrm{Cn} \mathrm{C}(0.267)$ and $\beta$-Cn B (0.186) were higher than in BV $(0.067$ and 0.196 respectively), whereas the frequency of $\beta$ - Lg B was lower for OSB (0.370) than for BV (0.598). LI and GAUNT (1972) reported the frequency 0.02 for $\alpha_{\mathrm{s} 1}-\mathrm{Cn} \mathrm{C}$ and 0.10 for $\beta$-Cn B for Brown Swiss in the USA. For the Brown cattle in Italy the frequency for $\alpha_{s 1}-\mathrm{Cn} C$ was 0.119 , for $\beta$-Cn B 0.280 and for $\beta$-Lg B 0.499 (Russo and MARIANI 1971). The frequencies 0.064, 0.258 and 0.559 , respectively, were reported for the same breed more recently by MARIANI (1987). A comparison of these allele frequencies in Italy shows that the frequencies of $\alpha_{\mathrm{s} 1}-\mathrm{Cn} \mathrm{C}$ and $\beta-\mathrm{Cn} \mathrm{B}$ had decreased over this period, whereas the frequency of $\beta$ - $\mathrm{Lg} \mathrm{B}$ had increased, meaning that the gene flow from BS in the populations of Brown cattle in Italy and Switzerland is similar.

It is difficult to find an appropriate explanation for the differences between the allele frequencies in the original Swiss breeds, OSS and OSB, on one hand, and in their crosses, FV and BV, with the American breeds, BS and RH, on the other. One of the reasons might be the crossing itself due to differences found between the original Swiss breeds and their crosses (Table 2). It is known that crossbreeding of original Swiss Simmental with American Red Holstein, and also of original Swiss Brown with American Brown Swiss, began around 1970 and is constantly increasing. Genetic improvement in dairy cattle has principally been dependent on quantitative genetics. This would suggest that dairy breeders have indirectly selected in favour of some genetic variants which are in positive correlation with the quantitative characteristics. This is affecting and altering the genetic make-up of milk proteins. It can be concluded that the variation in the frequencies of milk protein 
Table 2. Genotype frequencies of $\alpha_{\mathrm{s1}}{ }^{-}, \beta$ - and $\kappa$-casein and $\beta$-lactoglobulin for each breed and the differences between original and crossed breeds.

\begin{tabular}{|c|c|c|c|c|c|c|c|}
\hline \multirow[t]{2}{*}{ Genotype } & & \multicolumn{6}{|c|}{ Breed") } \\
\hline & & OSS & FV & Difference & OSB & BV & Difference \\
\hline & $\mathrm{n}=$ & 177 & 193 & & 204 & 380 & \\
\hline \multicolumn{8}{|l|}{$\alpha_{\mathrm{s} 1}-\mathrm{Cn}$} \\
\hline $\mathrm{AB}$ & & 0 & 0 & 0 & 0.005 & 0 & +0.005 \\
\hline BB & & 0.864 & 0.912 & -0.048 & 0.642 & 0.876 & -0.234 \\
\hline $\mathrm{BC}$ & & 0.136 & 0.088 & +0.048 & 0.333 & 0.113 & +0.220 \\
\hline $\mathrm{CC}$ & & 0 & 0 & 0 & 0.020 & 0.011 & +0.009 \\
\hline \multicolumn{8}{|l|}{$\beta-C n$} \\
\hline AlAl & & 0.051 & 0.223 & -0.172 & 0.020 & 0.026 & -0.006 \\
\hline $\mathrm{A} 1 \mathrm{~A} 2$ & & 0.282 & 0.378 & -0.096 & 0.181 & 0.166 & +0.015 \\
\hline A1B & & 0.017 & 0.016 & +0.001 & 0.093 & 0.058 & +0.035 \\
\hline AlC & & 0.028 & 0.047 & -0.019 & 0.005 & 0 & +0.005 \\
\hline $\mathrm{A} 2 \mathrm{~A} 2$ & & 0.373 & 0.202 & +0.171 & 0.314 & 0.434 & -0.120 \\
\hline A2B & & 0.079 & 0.026 & +0.053 & 0.333 & 0.258 & +0.075 \\
\hline A2C & & 0.153 & 0.109 & +0.044 & 0 & 0.018 & -0.018 \\
\hline BB & & 0.006 & 0 & +0.006 & 0.054 & 0.037 & +0.017 \\
\hline $\mathrm{BC}$ & & 0.011 & 0 & +0.011 & 0 & 0.003 & -0.003 \\
\hline \multicolumn{8}{|l|}{$\kappa-C n$} \\
\hline AA & & 0.294 & 0.358 & -0.064 & 0.279 & 0.168 & +0.111 \\
\hline $\mathrm{AB}$ & & 0.531 & 0.451 & +0.080 & 0.480 & 0.466 & +0.014 \\
\hline $\mathrm{AE}$ & & 0 & 0.021 & -0.021 & 0 & 0 & 0 \\
\hline AC & & 0 & 0 & 0 & 0.039 & 0.016 & +0.023 \\
\hline BB & & 0.220 & 0.171 & +0.049 & 0.167 & 0.334 & -0.167 \\
\hline $\mathrm{BC}$ & & 0 & 0 & 0 & 0.034 & 0.016 & +0.018 \\
\hline \multicolumn{8}{|l|}{$\beta-\mathrm{Lg}$} \\
\hline AA & & 0.153 & 0.093 & +0.060 & 0.402 & 0.158 & +0.244 \\
\hline $\mathrm{AB}$ & & 0.537 & 0.466 & +0.071 & 0.426 & 0.474 & -0.048 \\
\hline$A D$ & & 0.006 & 0 & +0.006 & 0.015 & 0.003 & +0.012 \\
\hline BB & & 0.299 & 0.440 & -0.141 & 0.157 & 0.355 & -0.198 \\
\hline $\mathrm{BD}$ & & 0.006 & 0 & +0.006 & 0 & 0.011 & -0.011 \\
\hline
\end{tabular}

genes between different populations are mainly, if not entirely, the result of breeding and crossing.

\section{Allele frequencies of $\kappa-\mathrm{Cn}$}

Allele frequencies in Table 1 show that $\kappa-\mathrm{Cn} \mathrm{A}$ and $B$ variants were predominant and that $\kappa-\mathrm{Cn} \mathrm{E}$ and $\mathrm{C}$ were rare. The $\kappa-\mathrm{Cn} \mathrm{E}$ variant was identified only in $\mathrm{FV}$ and $\kappa-\mathrm{Cn} \mathrm{C}$ variant in OSB and BV.
In OSS the difference in frequencies between $\kappa-\mathrm{Cn} \mathrm{A}(0.514)$ and $\kappa-\mathrm{Cn} \mathrm{B}(0.486)$ was not as pronounced as in $\mathrm{FV}$ where the frequencies were 0.593 and 0.396 , respectively. In OSB, the $\kappa-\mathrm{Cn}$ variants $\mathrm{A}, \mathrm{B}$ and $\mathrm{C}$ were present with frequencies of $0.539,0.424$ and 0.037 and in BV with 0.409 , 0.575 and 0.016 , respectively. The allele frequencies of $\kappa-\mathrm{Cn} \mathrm{A}$ and $\mathrm{B}$ in OSB and BV were different from those in OSS and FV. $\kappa-\mathrm{Cn} \mathrm{A}$ was predominant in OSS, FV and OSB, and $\kappa-\mathrm{Cn} \mathrm{B}$ in BV. 
Table 3. F-ratios for the overall effect and least squares mean and standard error of a 305-day milk yield for $\kappa$-Cn by breed.

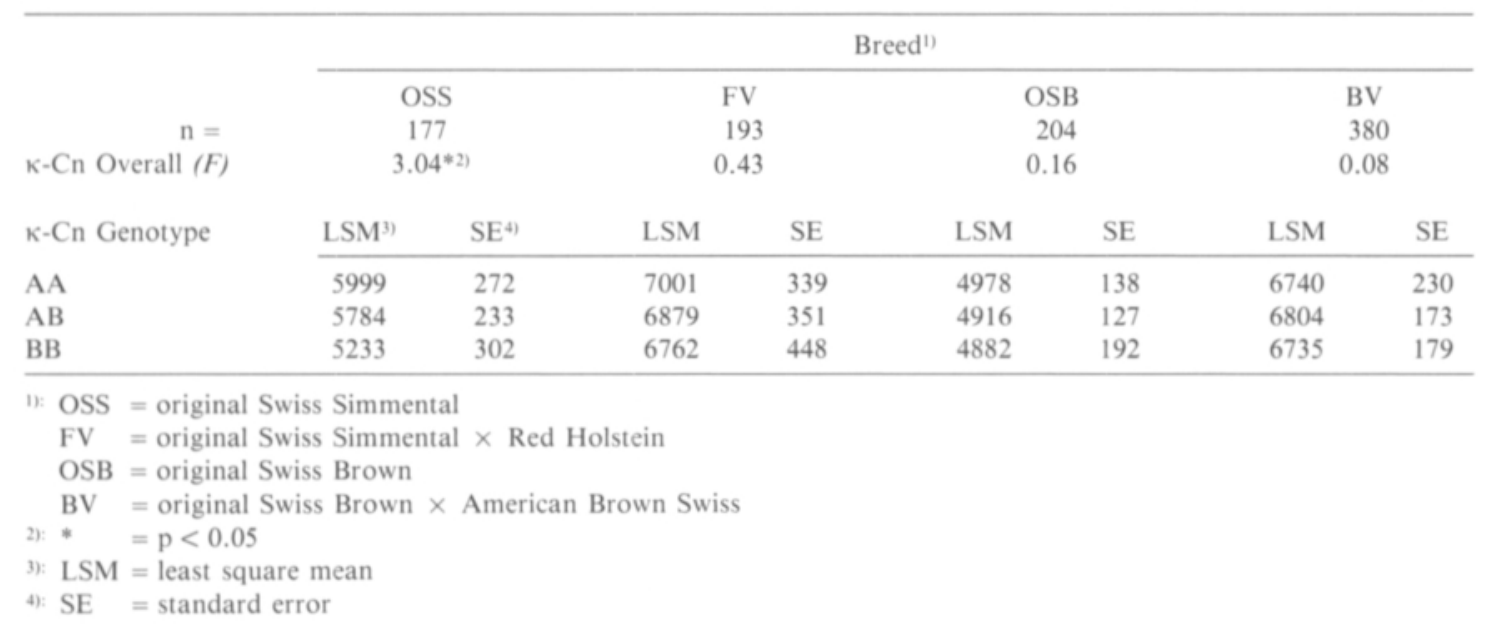

The results concerning the frequencies of $\kappa-\mathrm{Cn}$ variants in the studied populations agreed in many respects with those reported for Italy and Germany. MARIANI (1987) found allele frequencies of $\kappa-\mathrm{Cn}$ A : B : $\mathrm{C}=0.504: 0.490: 0.006$ and ERHARDT (1989) $\kappa-C n$ A : B : C $=0.505: 0.479: 0.016$ in the Brown cattle. LI and GAUNT (1972) reported the frequency 0.41 for $\kappa-\mathrm{Cn} \mathrm{A}$ and 0.59 for $\kappa-\mathrm{Cn} \mathrm{B}$ for Brown Swiss in the USA.

It was found that the highest $\mathrm{K}-\mathrm{Cn} \mathrm{B}$ (favourable variant) frequency occurred in $\mathrm{BV}(0.575)$ followed by OSS $(0.486)$, OSB $(0.424)$ and FV $(0.396)$. This might support the view that the frequency of $\kappa-\mathrm{Cn}$ $B$ increases in the Swiss Brown cattle population due to crossing with American Brown Swiss and decreases in the Simmental cattle population due to crossing with American Red Holstein. A comparison of the allele frequencies of $\kappa-\mathrm{Cn}$ in Austrian FV, reported in 1975 ( $\kappa-\mathrm{Cn}$ A 0.59 and $\kappa-\mathrm{Cn}$ B $0.41)$ by FoISSY and WINTERER and in 1991 ( $\kappa-\mathrm{Cn}$ A 0.70 and $\kappa-C n$ B 0.30 ) by MAYER et al., showed that the frequencies of $\kappa-\mathrm{Cn} A$ had increased whereas the frequency of $\kappa-\mathrm{Cn} \mathrm{B}$ had decreased during this period. The same result has also been observed in German dairy cattle by BUCHBERGER (1990) and in Danish dairy cattle by BECH and KRISTIANSEN (1990).

\section{$\kappa-C n$ variants and their relation to milk yield}

The results of the statistical analysis on the associations of $\kappa-\mathrm{Cn}$ variants with a 305-day lactation yield are presented in Table 3 .

For the majority of the breeds (FV, OSB and $\mathrm{BV}), \kappa-\mathrm{Cn}$ polymorphism was not significantly associated with the 305 -day lactation yield. For OSS, however, a significant $(\mathrm{p}<0.05)$ association was found between the $\kappa-\mathrm{Cn}$ locus and 305-day lactation yield.

When comparing the least squares means for the different $\kappa-\mathrm{Cn}$ genotypes, the FV cows with $\kappa-\mathrm{Cn}$ AA out produced those with $\mathrm{AB}$ and $\mathrm{BB}$ by 122 and $239 \mathrm{~kg}$ milk, respectively. For OSS, the differences were higher: cows with $\kappa-\mathrm{Cn}$ AA produced 215 and $766 \mathrm{~kg}$ milk more than those with $\kappa-\mathrm{Cn} \mathrm{AB}$ and $\mathrm{BB}$. For BV and OSB the differences were small. In a study by TAHA (1992) comprising the same animals as the present study but also including first-lactation cows and those with more than 10 lactations (11th, 12th and 13th lactation), the same tendencies were found but the differences between the $\kappa-\mathrm{Cn}$ genotypes were all non significant. Neither was there any significant overall effect of the $\kappa-\mathrm{Cn}$ locus on milk yield for any of the breeds.

Our results agree in some aspects with the works 
of MCLEAN et al. (1984) and ALEANDRI et al. (1990), who failed to find any association between $\kappa-\mathrm{Cn}$ and milk yield. In contrast, NG-KWAI-HANG et al. (1986) reported that a higher test-day milk production was associated with $\kappa-\mathrm{Cn} \mathrm{AA}$. LIN et al. (1989) demonstrated, however, that the $\kappa$-Cn locus had a significant effect on fixed parity and on fixed age total milk yield and herd life, and that cows with $\kappa-\mathrm{Cn} \mathrm{BB}$ produced more milk than those with $\kappa-\mathrm{Cn} \mathrm{AA}$ and $\mathrm{AB}$. He argued that first-lactation records alone should not be used when studying the association between $\kappa-\mathrm{Cn}$ variants and milk yield. We have reason to believe, moreover, that records from more than one lactation are needed to determine such association.

\section{Conclusion}

Our study suggests that before genetic variants of milk proteins, in particular $\kappa-\mathrm{Cn}$, are included in selection and breeding strategies, it is essential to account for the magnitude of both the effects of the different milk protein loci on quantitative traits such as milk yield as well as on traits of a more qualitative nature such as manufacturing properties.

\section{References}

Aaltonen, M. L. \& AnTIL.A, V. 1987. Milk renneting properties and the genetic variants of proteins. Milchwissenschaft 42: 490-492.

Aleandri, R., Buttazzoni, L. G. \& Schneider, J. C. 1990. The effects of milk protein polymorphisms on milk components. J. Dairy Sci. 73: 241-255.

BeCh, A.-M. \& Kristiansen, K. R. 1990. Milk protein polymorphism in Danish dairy cattle and the influence of genetic variants on milk yield. J. Dairy Res. 57: 53-62.

BuCHBERGER, J. 1990. Beeinflusst die Züchtung den technologischen Wert der Milch? Dte. Molk.-Ztg. 111: 8088.

DAvies, D. T. \& LAw, A. J. R. 1977. The composition of whole casein from the milk of Ayrshire cows. J. Dairy Res. 44: 447-454.

ERHARDT, G. 1989. א-Kasein in Rindermilch - Nachweis eines weiteren Allels $\left(\kappa-\mathrm{Cn}^{\mathrm{E}}\right)$ in verschiedenen Rassen. J. Anim. Breed. Genet. 106: 225-231.

FoISSY, H. \& WINTERER, H. 1975. Genetische Varianten der Milchproteine bei Österreichischem Fleckvieh. Österreichische Milchwirtschaft, Beilage 1 (zu Heft 8). 1-12.

JАКОВ, E. 1993. Beziehungen zwischen dem genetischen Polymorphismus der Milchproteine und der Labfähigkeit von Milch. Diss. ETH-Zürich Nr. 10224.

— \& PuHAN, Z. 1986. Unterschiede zwischen Labträger und normalgerinnender Milch unter besonderer Berücksichtigung der Caseinfraktion. Schweiz. Milch. Forschung 15: 27-35.

— \& Puhan, Z. 1992. Technological properties of milk as influenced by genetic polymorphism of milk protein - A review. Int. Dairy Journal 2: 157-178.

Kroeker, E. M., Ng-Kwal-Hang, K. F., Hayes, J. F. \& MoXley, E. 1985. Effects of environmental factors and milk protein polymorphism on composition of casein fraction in bovine milk. J. Dairy Sci. 68: 1752-1757.

Li, F. H. F. \& GaUNT, S. N. 1972. A Study of Genetic
Polymorphisms of Milk $\beta$-Lactoglobulin, $\alpha_{s 1}$-Casein, $\beta$-Casein, and $\kappa$-Casein in Five Dairy Breeds. Biochem. Genet. 6: 9-20.

Lin, C. Y., McAllister, A. J., NG-Kwal-Hang, K. F., HaYes, J. F., Batra, T. R., Lee, A. J., Roy, G. L., Vesely, J. A., W AUTHY, J. M. \& Winter, K. A. 1989. Relationships of milk protein types to lifetime performance. J. Dairy Sci. 72: 3085-3090.

MARIANI, P. 1987. Il polimorfismo genetico delle caseine in vacche di razza bruna: Frequenza della variante $\mathrm{C}$ al locus $\kappa-\mathrm{CN}$. Ann. Fac. Med. Veter., Univ. Parma VII: 317-332.

-, Losi, G., Russo, V., Castagnetti, G. B., Grazia, L., Morinı, D. \& FossA, E. 1976. Caseification tests made with milk characterized by variants $\mathrm{A}$ and $\mathrm{B}$ of $\kappa$-casein in the production of Parmigiano-Reggiano cheese. Sci. Tec. Latt.-Cas. 27: 208-227.

Marziali, A. S. \& NG-Kwal-Hang, K. F. 1986. Effects of milk composition and genetic polymorphism on coagulation properties of milk. J. Dairy Sci. 69: 1793-1798.

Mayer, H., Foissy, H. \& Schneglberger, H. 1991. Genetische Caseinvarianten bei Österreichischen Rinderrassen. Milchwirtschaftliche Berichte 108: 145-153.

MCLEAN, D. M. 1986. Influence of milk protein genetic variants on milk composition, yield and cheesemaking properties. XXth. International Conference on Animal Blood Groups and Biochemical Polymorphisms. Helsinki, Finland. Abstracts 121-123.

-, Graham, E. R. P., Ponzoni, R. W. \& McKenzie, H. A. 1984. Effects of milk protein genetic variants on milk yield and composition. J. Dairy Res. 51: 531-546.

Ng-Kwal-Hang, K. F., Hayes, J. F., Moxley, J. E. \& MonARDES, H. G. 1984. Association of genetic variants of casein and milk serum proteins with milk fat and protein production by dairy cattle. J. Dairy Sci. 67: 835-840.

—, Hayes, J. F., Moxley, J. E. \& Monardes, H. G. 1986. 
Relationships between milk protein polymorphisms and major milk constituents in Holstein-Friesian cows. J. Dairy Sci. 69: 22-26.

-, Monardes, H. G. \& haYes, J. F. 1990. Association between genetic polymorphism of milk proteins and production traits during three lactations. J. Dairy Sci. 73: 3414-3420.

Russo, V.\& MARIANI, P. 1971. Genetic polymorphism of the proteins in the milk of the Bruna alpina cows. Sci.Tecn. Latt.-Caseria 22: 167-183.

SAS 1988. SAS User's Guide. SAS Inst., Inc., Cary, NC.

SCHAAR, J. 1984. Effects of K-casein genetic variants and lactation number on the renneting properties of individual milks. J. Dairy Res. 51: 397-406.

Seibert, B., Erhardt, G. \& Senft, B. 1985. Procedure for simultaneous phenotyping of genetic variants in cow's milk by isoelectric focusing. Animal Blood Groups and Biochemical Genetics 16: 183-191.

-, Erhardt, G. \& Senft, B. 1987. Detection of a new $\kappa$-casein variant in cow's milk. Anim. Genet. 18: 269272.
TAнA, F. 1992. Variabilität der Stickstoff- und Eiweissfraktionen in der Milch von Betrieben mit Fleck- und Braunvieh. Diss. ETH-Zürich Nr. 9774.

Tervala, H.-L., AntIla, V. \& SyväJÄrvi, J. 1985. Factors affecting the renneting properties of milk. Meijeritieteellinen Aikakauskirja 43, 1: 16-25.

ZoGG, M. 1990. Gezielte Paarung im Hinblick auf KappaKasein. Schweizer Braunvieh. 5-6: 14-15.

Manuscript received April 1993

Dr. Fawzy Taha

Prof. Dr. Zdenko Puhan

Laboratory of Dairy Science

Swiss Federal Institute of Technology

ETH-Zentrum

CH-8092 Zürich, Switzerland

\title{
SELOSTUS
}

\section{Maidon $\kappa$-kaseiini- ja $\beta$-laktoglobuliini -jakeiden geneettinen polymorfia sveitsiläisellä lypsykarjalla}

\author{
FAWZY TAHA ja ZDENKO PUHAN
}

Laboratory of Dairy Science, Swiss Federal Institute of Technology

\begin{abstract}
Maitovalkuaisjakeissa esiintyvää geneettistä muuntelua tutkittiin neljällä sveitsiläisellä lypsykarjarotutyypillä. Koeaineistona käytettiin kaikkiaan 208 Original Swiss Simmental (OSS) -rodun lehmää, 220 Swiss Simmental- ja American Red Holstein $(\mathrm{RH})$-rotujen risteytysjälkeläistä, 215 Swiss Brown (OSB) -rodun lehmää ja 390 Swiss Brown- ja American Brown Swiss (BS) -rotujen risteytysjälkeläistä. Kaseiinien ja $\beta$-laktoglobuliinien geneettisen muuntelun lisăksi selvitettiin $\kappa$-kaseiinin ja maidon tuotantomäärän välisiä vuorovaikutussuhteita.
\end{abstract}

Rotujen välillä havaittiin jonkin verran alleelimuuntelua. Risteytettäessä OSS-rotuisia lehmiä RH-rodun kanssa havaittiin $\alpha_{\mathrm{s}-\mathrm{CnC}} \mathrm{C}-\mathrm{CnB}$ ja $\kappa-\mathrm{CnB}$ alleelien esiintymistiheyden văhenevän verrattuna OSS-rodun yksilöihin. Toisaalta $\beta$-LgB-alleelin määrän havaittiin kasvavan. OSB- ja BS-rotujen risteytyksissä $\alpha_{s 1}-\mathrm{CnC}$ - ja $\beta$-CnB -alleelien määrä väheni ja $\kappa-\mathrm{CnB}$ - ja $\beta$-LgB -alleelien määrä kasvoi. Ainoastaan OSS-roduilla havaittiin merkittävä vuorovaikutussuhde $\kappa-\mathrm{Cn}$ -lokuksen ja maidon määrän välillä. 